\title{
The Mitochondrial Genome of the Freshwater Crab Potamon fluviatile, the First Sequenced Representative of the Subfamily Potaminae and Its Phylogenetic Position within Potamidae
}

\author{
Adriana Vella ${ }^{1, *}$, Noel Vella ${ }^{1}$ \\ ${ }^{1}$ University of Malta, Department of Biology, Conservation Biology Research Group, Msida, Malta.
}

\section{How to cite}

Vella, A., Vella, N. (2022). The Mitochondrial Genome of the Freshwater Crab Potamon fluviatile, the First Sequenced Representative of the Subfamily Potaminae and Its Phylogenetic Position within Potamidae. Genetics of Aquatic Organisms, 6(3.Special Issue), GA460.

\section{Article History}

Received 01 October 2021

Accepted 17 December 2021

First Online 04 January 2022

\section{Corresponding Author}

Tel.: +35623402790

E-mail: adriana.vella@um.edu.mt

\section{Keywords}

Freshwater crab

Gene order

Mitogenome

Phylogeny

Potamidae

Potamon fluviatile

\begin{abstract}
Here we report the mitogenome of Potamon fluviatile collected from the Maltese islands, representing the first such study on species from the subfamily Potaminae. The mitogenome was analysed through next-generation sequencing and annotated. The genome was found to contain 37 genes that include 13 protein coding genes, 22 tRNA genes, two rRNA genes and a non-coding region. The gene order was compared to that of other Potamidae species, while protein coding and rRNA genes were used to evaluate the phylogenetic position of Potamon with other species of freshwater crabs. The phylogenetic analysis shows that the subfamily Potaminae, here represented by $P$. fluviatile, forms a distinct clade from its sister subfamily Potamiscinae, with the two sharing common ancestry within the family Potamidae. This study contributes to the genetic resources available for the genus Potamon.
\end{abstract}

\section{Introduction}

Potamon fluviatile (Herbst, 1785), is a primary freshwater crab that is found to occur in the southern European continent, in a number of hydrogeographically isolated freshwater bodies in Italy; the Balkan Peninsula; the Turkish Thrace region; and some neighbouring islands, including the Maltese Islands (Cumberlidge, 2008; Ng et al., 2008; Jesse et al., 2009; Harlığlu, Farhadi \& Harlığlu, 2018). Consequently, this species even though widespread, its distribution is highly fragmented even on small-scale given that it is restricted to fresh watercourses (Vella \& Vella, 2020). Additionally, it is highly threatened by anthropogenic activities mainly because of the pressures imposed on freshwater bodies including pollution, pesticides, alien species and water usage (Barbaresi, Cannicci, Vannini \& Fratini, 2007;
Cumberlidge et al., 2009; Freyhof \& Brooks, 2011; Vella, Vella \& Mifsud, 2017, Gozlan, Karimov, Zadereev, Kuznetsova \& Brucet, 2019; Grzybowski \& GlińskaLewczuk, 2019). These threats have led IUCN to enlist this species as Nearly Threatened on a global scale with populations showing negative trends (Cumberlidge, 2008, Cumberlidge et al., 2009). In the Maltese archipelago, this is the only species of freshwater crabs and is locally protected, while it is considered as a flagship species for freshwater habitats and also for invertebrates as $P$. fluvitale is considered as the national invertebrate (Laws of Malta, 2021).

Potamon fluviatile is a member of the family Potamidae Ortmann, 1896. The latter is a large family of primary freshwater crabs containing two subfamilies, Potaminae Ortmann, 1896 and Potamiscinae Bott, 1970 (Ng et al., 2008). In the past few years, attention has been given to the taxonomy and systematics of this 
family due to its conservation value and high species diversity, with works leading to the discovery of new species (Daniels et al., 2006; Ng et al., 2008; Yeo et al., 2008; Shih, Yeo \& Ng, 2009; Leelawathanagoon, Lheknim \& Ng, 2010). Huang, Shih \& Mao, 2016; Naruse, Chia \& Zhou, 2018; Zou, Bai \& Zhou, 2018; Gao et al. 2019; Wang, Zhou \& Zou, 2019; Wang, Zhou \& Zou, 2020; Tan, Zhou \& Zou, 2021). In 2008, a checklist of the subfamily Potaminae enlisted 34 species ( $\mathrm{Ng}$ et al., 2008), with the genus Potamon being its largest genus with 17 species, and since then a new species has been described by Jesse et al., (2010). While some of these species, including $P$. fluviatile, have been DNA barcoded for systematic studies or included in population studies (Jesse et al., 2009; Jesse et al., 2010; Jesse et al., 2011; Vella and Vella, 2020), yet data on Potamidae mitochondrial genomes is limited to the subfamily Potamiscinae, while none from the subfamily Potaminae have ever been studied for the complete set of mitochondrial genes and gene order.

In Potamiscinae the mitogenomes range from 15,318 bp in Nanhaipotamon hongkongense (Wang et al., 2020), to at least $20,227 \mathrm{bp}$ in the incomplete mitogenome of Parapotamon spinescens (Zhang et al., 2020) (Table 1). Some of these Potamiscinae mitogenomes exhibit different gene arrangements, including tandem duplication or random loss events in non-coding sequences, single gene duplication, tRNA remolding, transposition and inversion transposition of genes, leading to at least nine distinct mitogenomic gene order patterns, with eight of them deviating from the typical brancyuran mitogenome ground pattern (Zhang et al. 2020). These interesting variations in the mitogenomes of Potamiscinae species have led to better understand the evolutionary history of different freshwater crabs at subfamily level (Zhang et al. 2020), yet the absence of studies on Potaminae limits the understanding of the phylogenetic relationships within the family Potamidae.

The current study uses the mitochondrial genome sequence to elucidate its organization, gene order and codon usage in $P$. fluviatile and at the same time compare it with that of other freshwater crabs. This phylogenetic contribution is essential as it uses a large set of genes to investigate the systematic position and the taxonomic relationship between the two subfamilies within Potamidae, that is Potaminae and Potamiscinae, adding knowledge on the systematics of primary freshwater crabs.

Table 1. The mitogenome composition of different Potamidae species.

\begin{tabular}{|c|c|c|c|c|c|}
\hline Species & GenBank & $\begin{array}{c}\text { Mitogenome } \\
\text { length bp (GC\%) }\end{array}$ & $\begin{array}{c}\text { Protein-coding } \\
\text { genes length bp } \\
(\mathrm{GC} \%)\end{array}$ & $\begin{array}{c}\text { Ribosomal } \\
\text { RNA genes } \\
\text { length bp } \\
\text { (GC\%) }\end{array}$ & Reference \\
\hline \multicolumn{6}{|l|}{ Potaminae } \\
\hline Potamon fluviatile & OL944387 & $16,037(26.6)^{*}$ & $11,174(28.6)$ & $2,120(22.2)$ & current work \\
\hline \multicolumn{6}{|l|}{ Potamiscinae } \\
\hline Aparapotamon similium & МK950854 & $19,236(27.2)$ & $11,145(30.2)$ & $2,146(25.3)$ & Lie et al., 2019 \\
\hline Apotamonautes hainanensis & MN737137 & $17,011(26.6)$ & $11,158(28.0)$ & $2,236(22.8)$ & Zhang et al., 2020 \\
\hline Bottapotamon lingchuanense & MN117717 & $17,612(27.7)$ & $11,186(30.4)$ & $2,146(25.4)$ & Wang et al., 2021 \\
\hline Candidiopotamon okinawense & MN737145 & $17,211(27.7)$ & 11,155 (29.9) & $2,133(23.5)$ & Zhang et al., 2020 \\
\hline Chinapotamon maolanense & MT134100 & $17,130(26.6)$ & $11,122(29.6)$ & $2,143(23.0)$ & Cui et al., 2020 \\
\hline Geothelphusa dehaani & AB187570 & $18,197(25.1)^{*}$ & $11,137(28.5)$ & $2,136(23.2)$ & Segawa et al., 2005 \\
\hline Huananpotamon lichuanense & KX639824 & $15,380(26.8)$ & $11,127(28.5)$ & $2,144(22.3)$ & Bai et al., 2018 \\
\hline Indochinamon bhumibol & MT872370 & $16,351(29.7)$ & $11,142(32.0)$ & $1,893(26.5)$ & Naktang et al., 2021 \\
\hline Longpotamon depressum & MW182411 & $16,537(26.7)$ & $11,143(28.8)$ & $2,095(22.9)$ & Wang et al., 2021 \\
\hline Longpotamon exiguum & MW182410 & $17,324(26.2)^{*}$ & $11,149(29.1)$ & $2,134(23.2)$ & Wang et al., 2021 \\
\hline Longpotamon kenliense & MK584299 & $18,499(25.5)$ & $11,170(29.1)$ & $2,121(23.3)$ & Wang et al., 2020 \\
\hline Longpotamon parvum & MN737134 & $19,637(26.0)$ & $11,161(30.5)$ & $2,139(24.6)$ & Zhang et al., 2020 \\
\hline Longpotamon xiushuiense & KU042041 & $18,460(25.5)$ & $11,172(29.0)$ & $2,138(23.0)$ & unpublished \\
\hline Longpotamon yangtsekiense & KY785879 & $17,885(25.0)$ & $11,155(28.2)$ & $2,120(22.7)$ & Yuhui et al., 2017 \\
\hline Lophopotamon yenyuanense & MN737139 & $18,869(27.1)$ & $11,154(30.3)$ & $2,123(25.0)$ & Zhang et al., 2020 \\
\hline Nanhaipotamon hongkongense & MW125541 & $15,318(27.3)$ & $11,136(29.0)$ & $2,122(23.7)$ & Wang et al., 2021 \\
\hline Neilupotamon sinense & MN737143 & $18,894(32.6)$ & $11,169(36.0)$ & $2,159(29.3)$ & Zhang et al., 2020 \\
\hline Neilupotamon xinganense & MN117718 & 16,965 (32.9) & $11,150(35.6)$ & $2,156(28.4)$ & Tan et al., 2020 \\
\hline Parapotamon spinescens & MN737144 & $20,227(22.8)^{*}$ & $11,143(26.8)$ & $2,144(22.3)$ & Zhang et al., 2020 \\
\hline Potamiscus montosus & MN737133 & $16,299(27.3)$ & $11,148(29.3)$ & $2,156(24.1)$ & Zhang et al., 2020 \\
\hline Potamiscus motuoensis & MN737138 & $18,257(28.2)$ & $11,152(31.3)$ & $2,126(25.7)$ & Zhang et al., 2020 \\
\hline Potamiscus yiwuensis & MN737136 & $16,307(27.4)$ & $11,148(29.4)$ & $2,157(24.2)$ & Zhang et al., 2020 \\
\hline Potamiscus yongshengensis & MN737142 & $17,821(29.4)$ & $11,148(32.0)$ & $2,130(25.7)$ & Zhang et al., 2020 \\
\hline Sinolapotamon patellifer & MK883709 & $16,547(23.6)$ & $11,142(25.6)$ & $2,196(21.3)$ & Ji et al., 2019 \\
\hline Sinopotamon yaanense & KY785880 & $17,126(26.6)$ & $11,151(29.3)$ & $2,120(23.8)$ & Yuhui et al., 2017 \\
\hline Tenuilapotamon latilum & MN737132 & $19,582(26.6)^{*}$ & $11,158(30.3)$ & $2,140(24.5)$ & Zhang et al., 2020 \\
\hline Tenuipotamon yuxiense & MN737140 & 18,404 (28.9) & 11,145 (31.7) & $2,125(26.0)$ & Zhang et al., 2020 \\
\hline Terrapotamon thungwa & MW697087 & $16,156(26.8)$ & $11,136(28.6)$ & $2,132(23.5)$ & unpublished \\
\hline mean values & & $\begin{array}{c}17,561 \pm 1299 \\
(27.1 \pm 2.1)\end{array}$ & $\begin{array}{l}11,151 \pm 14 \\
(30.1 \pm 2.2)\end{array}$ & $\begin{array}{c}2,132 \pm 53 \\
(24.2 \pm 1.8)\end{array}$ & \\
\hline
\end{tabular}

* mitogenome contains a gap or was not circularized due to a gap in the sequence. 


\section{Materials and Methods}

\section{Sample Collection and DNA Extraction}

A specimen of $P$. fluviatile collected from the freshwater stream at Bahrija valley $\left(35^{\circ} 53^{\prime} 40.40^{\prime \prime} \mathrm{N}\right.$, $14^{\circ} 20^{\prime} 20.11^{\prime \prime E}$ ) was tissue sampled for this study. This live specimen was sampled through the collection of one walking leg as indicated in Permit NP 0176/18/33A and has already contributed towards a population study on this species in the Maltese archipelago (Vella and Vella, 2020). Upon collection the tissue sample was stored in $100 \%$ ethanol and soon after the total genomic DNA was extracted using GF-1 Tissue DNA Extraction Kit (Vivantis Technologies, Malaysia) following the manufacturer's manual. The purified DNA was stored at $-20^{\circ} \mathrm{C}$.

\section{Library Construction, Mitogenome Assembly and Annotation}

A DNA library of the whole genome was constructed and sequenced using $2 \times 150 \mathrm{bp}$ paired-end sequencing through Illumina HiSeq 2500 (Illumina, USA). DNA sequences were paired, trimmed at $\geq$ Q40, and reads shorter than 100 nucleotides were discarded. The final data set was de novo assembled using Geneious R10 (Kearse et al., 2012). Once the mitogenome was obtained, the PCGs were identified through homology with other Potamidae species obtained from GenBank (refer to Table 1). These genes were then translated using the invertebrate mitochondrial genetic code and checked for the presence of the predicted start codons, for the positions of the stop codons, and for possible insertions and deletions that would have caused a frameshift using Geneious R10 (Kearse et al., 2012). The software tRNAscan-SE 2.0 (Chan \& Lowe, 2019) and ARWEN (Laslett \& Canback, 2008) were used to determine the genomic position and the secondary structure for each tRNA, that were identified through their cloverleaf secondary structure and anticodon sequence. The annotated mitogenome was then validated against published mitogenomes of other Potamidae species (refer to Table 1). Nucleotide composition statistics, relative synonymous codon usage, and analyses of AT-skew and GC-skew were also carried out.

\section{Mitogenome Phylogenetic Analysis}

The sequence obtained in this study was used to investigate the phylogenetic relationships between $P$. fluviatile, other Potamidae species and other freshwater crabs from the family Gecarcinucidae, using the concatenated data of PCGs and rRNA genes data. Noncoding sequences and tRNAs were not included during this analysis due to their variability arising from tandem duplication and random loss events, gene duplication, tRNA remolding, transpositions and inversion transpositions even between closely related taxa (Zhang et al., 2020). Sequences were aligned using ClustalW (Thompson et al., 1994), while MEGA v10 (Kumar et al., 2018) was used to construct a maximum-likelihood phylogenetic tree (Figure 1) using 1,000 bootstrap and $\mathrm{GTR}+\mathrm{G}+\mathrm{l}$ as it was identified as the best substitution model through the same software.

\section{Results}

\section{Mitogenome Organization}

The whole genome sequencing for $P$. fluviatile produced $7.9 \times 10^{7}$ pair-end reads. After de novo assembly, the sequence of the mitochondrial genome was achieved with an average coverage of 2,796 (SD \pm 276$)$. This mitochondrial genome (GenBank accession no. OL944387) was $16,037 \mathrm{bp}$, and was partially incomplete due to the presence of a gap arising from tandem repeats in the non-coding region meaning that it could not be circularized unambiguously between $12 \mathrm{~S}$ rRNA gene and the tRNA-lle. This work represents the first mitochondrial genome for the subfamily Potaminae. The overall base composition is $35.8 \% \mathrm{~A}$, $16.2 \% \mathrm{C}, 10.3 \% \mathrm{G}$ and $37.6 \% \mathrm{~T}$, with a GC content of $26.6 \%$. As expected the mitogenome contains 37 coding genes that is, 2 ribosomal RNA ( $12 \mathrm{~S}$ and 16S) genes, 22 tRNA genes and 13 PCGs. Most of these genes (23) are encoded on the H-strand, while the ND5, ND4, ND4L, ND1, 8 tRNA genes [GIn, Cys, Tyr, His, Phe, Pro, Leu ${ }^{1}$, Val] and the two rRNA genes are encoded on the L-strand (Table 2).

The AT and GC skews were calculated using $(A-T) /(A+T)$ and $(G-C) /(G+C)$ respectively. The overall AT skew for the genes was -0.12 , indicating a higher $T$ content than A content, while the GC skew was 0.06 , indicating that the $\mathrm{G}$ content is only slightly higher than C content. The AT and the GC skews of the genes on the $\mathrm{H}$-strand was -0.14 for both skews, while for the genes on the L-strand the values were -0.10 and 0.31 respectively. The latter indicates that the genes encoded on the L-strand have a high proportion of $\mathrm{G}$ content when compared to the $C$ content, in fact this GC skew is also reflected in the rRNA genes given that both occur on the L-strand (Table 2).

\section{Protein-coding Genes}

The mitogenome contains $11,174 \mathrm{bp}$ that code for PCGs, which add up to a total of 3,724 amino acids. The gene length varies between $1,729 \mathrm{bp}$ for ND5 to $159 \mathrm{bp}$ for ATP8. Most of the PCGs begin with ATG except for ND5 and ND6 that begin with ATT, and ATP6 and ND3 that use ATA as the start codon. For these PCGs the most common stop codon is TAA, although some use TAG (CO3, ND3, ND4) and the incomplete stop codon T(ND5, CYTB). Overlapping nucleotides between PCGs are present between: ATP6 and ATP8 genes; between ND4L and ND4 genes; and the stop codon of ND6 with CYTB. While the longest non-coding intergenic region is $31 \mathrm{bp}$ 
and occurs between the ND5 and ND4 genes. The most commonly used amino acids are Leu (15.5\%), Ser (9.8\%) and lle (9.3\%) (Table 3). The relative synonymous codon usage for the PCGs is summarized in Table 3. All PCGs have a negative AT skew, except ND1, ND4, ND4L and ND5, which are encoded on the L-strand. All genes have a negative GC skew, except CO1 for which the GC skew value is zero.

\section{Transfer RNAs and Ribosomal RNAs}

The tRNAs in $P$. fluviatile vary in size from $62 \mathrm{bp}$ in tRNA-Ala, tRNA-Asn, tRNA-Arg and tRNA-Gly, to 72 bp in tRNA-Val (Table 2), with an overall $25.3 \%$ GC content,
0.04 AT-skew and 0.13 GC-skew. The two rRNA genes are separated by tRNA-Val gene, and vary in length from $817 \mathrm{bp}$ for the $12 \mathrm{~S}$ rRNA to $1,303 \mathrm{bp}$ for the 16S rRNA gene. Their overall GC content is $22.2 \%$, with a 0.02 and 0.30 AT-skew and GC-skew respectively (Table 2 ).

\section{Phylogenetic Analysis}

This analysis shows that Potaminae, here represented by the currently sequenced $P$. fluviatile, is clustered within the family Potamidae, and is a sister to the subfamily Potamiscinae, a relationship that was confirmed with high statistical support.

Table 2. Characteristics of the Potamon fluviatile mitochondrial genome coding genes.

\begin{tabular}{|c|c|c|c|c|c|c|c|c|c|c|}
\hline Gene & $\begin{array}{c}\text { Position } \\
\text { (from - to) }\end{array}$ & $\begin{array}{l}\text { Length } \\
\text { (bp) }\end{array}$ & $\begin{array}{l}\text { Start / Stop } \\
\text { codon }\end{array}$ & $\begin{array}{l}\text { Amino } \\
\text { acids }\end{array}$ & Anticodon & $\mathrm{GC} \%$ & $\begin{array}{c}\text { AT } \\
\text { skew }^{a}\end{array}$ & $\begin{array}{c}\text { GC } \\
\text { skew }^{b}\end{array}$ & IGN & Strand \\
\hline tRNA-Ile & $956-1,025$ & 70 & & & GAT & 30.0 & 0.04 & 0.05 & & $\mathrm{H}$ \\
\hline tRNA-GIn & $1,025-1,093$ & 69 & & & TTG & 24.6 & -0.04 & 0.65 & -1 & $\mathrm{~L}$ \\
\hline tRNA-Met & $1,108-1,177$ & 70 & & & CAT & 30.0 & 0.02 & -0.14 & +14 & $\mathrm{H}$ \\
\hline ND2 & $1,178-2,188$ & 1,011 & ATG / TAA & 336 & & 25.4 & -0.19 & -0.35 & 0 & $\mathrm{H}$ \\
\hline tRNA-Trp & $2,186-2,251$ & 66 & & & TCA & 15.2 & 0.18 & -0.20 & +3 & $\mathrm{H}$ \\
\hline tRNA-Cys & $2,250-2,312$ & 63 & & & GCA & 27.0 & 0.04 & 0.18 & -2 & $\mathrm{~L}$ \\
\hline tRNA-Tyr & $2,313-2,376$ & 64 & & & GTA & 28.1 & -0.09 & 0.33 & 0 & $\mathrm{~L}$ \\
\hline CO1 & $2,377-3,915$ & 1,539 & ATG / TAA & 512 & & 33.1 & -0.16 & 0.00 & 0 & $\mathrm{H}$ \\
\hline tRNA-Leu ${ }^{2}$ & $3,911-3,976$ & 66 & & & TAA & 30.3 & 0.17 & 0.20 & -5 & $\mathrm{H}$ \\
\hline $\mathrm{CO} 2$ & $3,996-4,682$ & 687 & ATG / TAA & 228 & & 29.5 & -0.09 & -0.12 & +19 & $\mathrm{H}$ \\
\hline tRNA-Lys & $4,685-4,749$ & 65 & & & TTT & 40.0 & -0.03 & 0.00 & +2 & $\mathrm{H}$ \\
\hline tRNA-Asp & $4,751-4,816$ & 66 & & & GTC & 21.2 & -0.15 & 0.00 & +1 & $\mathrm{H}$ \\
\hline ATP8 & $4,817-4,975$ & 159 & ATG / TAA & 52 & & 21.4 & -0.23 & -0.53 & 0 & $\mathrm{H}$ \\
\hline ATP6 & $4,972-5,643$ & 672 & ATA / TAA & 223 & & 30.1 & -0.16 & -0.21 & -4 & $\mathrm{H}$ \\
\hline $\mathrm{CO} 3$ & $5,643-6,434$ & 792 & ATG / TAG & 263 & & 33.1 & -0.18 & -0.10 & -1 & $\mathrm{H}$ \\
\hline tRNA-Gly & $6,434-6,495$ & 62 & & & TCC & 25.8 & 0.09 & 0.00 & -1 & $\mathrm{H}$ \\
\hline ND3 & $6,493-6,849$ & 357 & ATA / TAG & 118 & & 26.6 & -0.15 & -0.14 & -3 & $\mathrm{H}$ \\
\hline tRNA-Ala & $6,849-6,910$ & 62 & & & TGC & 24.2 & 0.02 & 0.20 & -1 & $\mathrm{H}$ \\
\hline tRNA-Arg & $6,913-6,974$ & 62 & & & TCG & 29.0 & 0.00 & -0.11 & +2 & $\mathrm{H}$ \\
\hline tRNA-Asn & $6,945-7,036$ & 62 & & & GTT & 30.6 & 0.02 & 0.16 & 0 & $\mathrm{H}$ \\
\hline tRNA-Ser ${ }^{1}$ & $7,035-7,103$ & 69 & & & TCT & 24.6 & 0.08 & 0.06 & -2 & $\mathrm{H}$ \\
\hline tRNA-Glu & $7,126-7,192$ & 67 & & & TTC & 17.6 & 0.00 & 0.00 & +22 & $\mathrm{H}$ \\
\hline tRNA-His & $7,208-7,272$ & 65 & & & GTG & 24.6 & 0.06 & 0.25 & +15 & $\mathrm{~L}$ \\
\hline tRNA-Phe & $7,272-7,337$ & 66 & & & GAA & 22.7 & 0.10 & 0.47 & -1 & $\mathrm{~L}$ \\
\hline ND5 & $7,337-9,065$ & 1,729 & ATT / T- & 576 & & 26.8 & -0.14 & 0.28 & -1 & $\mathrm{~L}$ \\
\hline ND4 & $9,097-10,437$ & 1,341 & ATG / TAG & 446 & & 26.0 & -0.17 & 0.32 & +31 & $\mathrm{~L}$ \\
\hline ND4L & $10,431-10,733$ & 303 & ATG / TAA & 100 & & 26.4 & -0.23 & 0.45 & -7 & $\mathrm{~L}$ \\
\hline tRNA-Thr & $10,736-10,798$ & 63 & & & TGT & 20.6 & 0.04 & 0.08 & +2 & $\mathrm{H}$ \\
\hline tRNA-Pro & $10,799-10,863$ & 65 & & & TGG & 18.5 & 0.06 & 0.50 & 0 & $\mathrm{~L}$ \\
\hline ND6 & $10,866-11,372$ & 507 & ATT / TAA & 168 & & 25.8 & -0.27 & -0.36 & +2 & $\mathrm{H}$ \\
\hline СYTB & $11,372-12,506$ & 1,135 & ATG / T- & 378 & & 31.5 & -0.15 & -0.16 & -1 & $\mathrm{H}$ \\
\hline tRNA-Ser ${ }^{1}$ & $12,507-12,570$ & 64 & & & TGA & 20.3 & 0.14 & -0.08 & 0 & $\mathrm{H}$ \\
\hline ND1 & $12,590-13,531$ & 942 & GTG / ATT & 313 & & 27.2 & -0.25 & 0.29 & +19 & $\mathrm{~L}$ \\
\hline tRNA-Leu ${ }^{1}$ & $13,562-13,626$ & 65 & & & TAG & 23.1 & 0.00 & 0.33 & +30 & $\mathrm{~L}$ \\
\hline 16S rRNA & $13,627-14,929$ & 1,303 & & & & 22.1 & 0.02 & 0.31 & 0 & $\mathrm{~L}$ \\
\hline tRNA-Val & $14,930-15,001$ & 72 & & & TAC & 27.8 & 0.08 & 0.10 & 0 & $\mathrm{~L}$ \\
\hline 12S rRNA & $15,002-15,818$ & 817 & & & & 22.3 & 0.03 & 0.30 & 0 & $\mathrm{~L}$ \\
\hline All genes & & 14,737 & & & & 27.4 & -0.12 & 0.06 & & \\
\hline Genes H-strand & & 7,773 & & & & 29.4 & -0.14 & -0.14 & & \\
\hline Genes L-strand & & 6,964 & & & & 25.1 & -0.10 & 0.31 & & \\
\hline PCGs & & 11,174 & & & & 28.6 & -0.17 & 0.01 & & \\
\hline rRNAs & & 2,120 & & & & 22.2 & 0.02 & 0.30 & & \\
\hline tRNAs & & 1,443 & & & & 25.3 & 0.04 & 0.13 & & \\
\hline
\end{tabular}

${ }^{a}(A-T) /(A+T) ;{ }^{b}(G-C) /(G+C) ;{ }^{c}$ Intergenic nucleotides 
Table 3. The number of codons and the relative synonymous codon usage (number/RSCU) in Potamon fluviatile mitochondrial PCGs.

\begin{tabular}{|c|c|c|c|c|c|c|c|}
\hline Codon & & Codon & & Codon & & Codon & \\
\hline UUU(F) & $290 / 1.70$ & $\mathrm{UCU}(\mathrm{S})$ & $119 / 2.62$ & UAU(Y) & $127 / 1.58$ & UGU(C) & $26 / 1.44$ \\
\hline UUC(F) & $51 / 0.30$ & $\mathrm{UCC}(\mathrm{S})$ & $21 / 0.46$ & UAC(Y) & 34 / 0.42 & UGC(C) & $10 / 0.56$ \\
\hline UUA(L) & $390 / 4.04$ & UCA(S) & $78 / 1.71$ & UAA $\left(^{*}\right)$ & $8 / 1.80$ & UGA(W) & $67 / 1.35$ \\
\hline UUG(L) & 30 / 0.31 & UCG(S) & $8 / 0.18$ & UAG(*) & $3 / 0.70$ & UGG(W) & $32 / 0.65$ \\
\hline $\operatorname{CUU}(\mathrm{L})$ & 93 / 0.96 & $\mathrm{CCU}(\mathrm{P})$ & 71 / 1.93 & $\mathrm{CAU}(\mathrm{H})$ & 55 / 1.39 & $\mathrm{CGU}(\mathrm{R})$ & $19 / 1.33$ \\
\hline $\operatorname{CUC}(\mathrm{L})$ & $16 / 0.17$ & $\mathrm{CCC}(\mathrm{P})$ & $12 / 0.33$ & $\mathrm{CAC}(\mathrm{H})$ & $24 / 0.61$ & $C G C(R)$ & $5 / 0.35$ \\
\hline $\operatorname{CUA}(\mathrm{L})$ & $45 / 0.47$ & $\operatorname{CCA}(\mathrm{P})$ & $51 / 1.39$ & $\operatorname{CAA}(Q)$ & $50 / 1.59$ & $C G A(R)$ & $29 / 2.04$ \\
\hline CUG(L) & $5 / 0.05$ & CCG $(P)$ & $13 / 0.35$ & CAG(Q) & $13 / 0.41$ & CGG $(R)$ & 4 / 0.28 \\
\hline$A U U(I)$ & $315 / 1.80$ & $\mathrm{ACU}(\mathrm{T})$ & $97 / 2.03$ & $\mathrm{AAU}(\mathrm{N})$ & $113 / 1.60$ & $A G U(S)$ & $31 / 0.68$ \\
\hline$A \cup C(I)$ & 34 / 0.20 & $A C C(T)$ & 19 / 0.40 & $\mathrm{AAC}(\mathrm{N})$ & $28 / 0.40$ & $A G C(S)$ & $7 / 0.15$ \\
\hline $\mathrm{AUA}(\mathrm{M})$ & $204 / 3.47$ & $\mathrm{ACA}(\mathrm{T})$ & 64 / 1.34 & $\mathrm{AAA}(\mathrm{K})$ & 85 / 1.81 & AGA(S) & 75 / 1.65 \\
\hline AUG(M) & $28 / 0.48$ & $A C G(T)$ & $11 / 0.23$ & $A A G(K)$ & $9 / 0.19$ & $A G G(S)$ & $25 / 0.55$ \\
\hline GUU(V) & $81 / 1.49$ & $\mathrm{GCU}(\mathrm{A})$ & 95 / 2.10 & GAU(D) & $52 / 1.49$ & GGU(G) & 75 / 1.27 \\
\hline GUC(V) & $7 / 0.13$ & $G C C(A)$ & $29 / 0.64$ & GAC(D) & $18 / 0.51$ & $\mathrm{GGC}(\mathrm{G})$ & $18 / 0.31$ \\
\hline GUA(V) & $121 / 2.23$ & $\mathrm{GCA}(\mathrm{A})$ & $51 / 1.13$ & $\mathrm{GAA}(\mathrm{E})$ & $52 / 1.39$ & GGA(G) & $91 / 1.54$ \\
\hline GUG(V) & $9 / 0.15$ & GCG $(A)$ & $6 / 0.13$ & GAG(E) & $23 / 0.61$ & GGG(G) & $52 / 0.88$ \\
\hline
\end{tabular}

\section{Discussion}

The variation in the mitochondrial genome length of Potamidae species is mainly driven by variation in the sequence length of the relatively long non-coding regions, which are at times characterized by tandem repeat elements increasing difficulty in circularizing sequences unambiguously. On the other hand, coding genes vary very little in size from one species to another (Table 1), with the coding genes in P. fluviatile being within the expected range for Potamidae species (PCGs from $11,122 \mathrm{bp}$ to $11,186 \mathrm{bp}$; rRNA from $1,893 \mathrm{bp}$ to $2,236 \mathrm{bp}$ ). This mitogenome exhibited 22 tRNA genes, that is the typical number of such genes in mitogenomes, though it is known that some mitogenomes of freshwater crab species, such as Sinopotamon parvum, Tenuilapotamon latilum and Geothelphusa dehaeni have undergone events such as gene duplication and possible tRNA remolding leading to a larger number of tRNAs (Zhang et al., 2020).

The gene order in the mitogenome of $P$. fluviatile did not show any deviation from the putative ancestral gene order identified as brancyuran mitogenome ground pattern in Zhang et al., (2020). While this pattern is likely to have occurred in the common ancestor the subfamily Potamiscinae as it is the most common gene order in this subfamily, yet a number of potamiscine species deviate from it by having different gene order rearrangements namely due to transposition, inversion transposition or duplication (Segawa \& Aotsuka, 2005; Zhang et al., 2020). Identifying the ground patter in $P$. fluviatile, that is within the subfamily Potaminae, further confirms that this arrangement is an ancestral arrangement for the family Potamidae.

The phylogenetic analysis covered in this study further corroborated the work of Zhang et al., 2020, who indicated that the subfamily Potamiscinae is monophyletic. In the latter study this subfamily was found to be monophyletic when compared to the family Gecarcinucidae and other marine crabs as outgroup.
The current study, through the data on $P$. fluviatile, we were able to compare the phylogenetic connection between subfamily Potaminae and the subfamily Potamiscinae. Here mitogenomic data confirmed that the subfamily Potaminae forms a distinct clade from its sister subfamily Potamiscinae, with the two sharing common ancestry which is supported by a bootstrap value of 100 (Figure 1). Together these two subfamilies form Potamidae ( $\mathrm{Ng}$ et al., 2008), which is here represented as a monophyletic family distinct from Gecarcinucidae, that is another family of freshwater crabs. This confirms the outcome of previous molecular studies that used smaller DNA sequences for analyses (Klaus et al., 2009; Shih et al., 2009; Tsang et al., 2014).

\section{Conclusion}

In this study, we sequenced and annotated the first mitogenome for the subfamily Potaminae, as represented by $P$. fluviatile, adding valuable data to a better understanding of the phylogenetic and evolution patterns within Potamidae. Moreover, this work provides the required information to enhance the molecular identification of freshwater crabs and population studies assisting conservation efforts of this species that occurs in highly fragmented populations (Vella and Vella, 2020).

\section{Ethical Statement}

This study made use of a handling and nonlethal tissue sampling permit for conservation research from the local environment protection authority.

\section{Funding Information}

The research disclosed in this publication has been funded through BioCon_Innovate Research Excellence Grant from the University of Malta awarded to AV. 


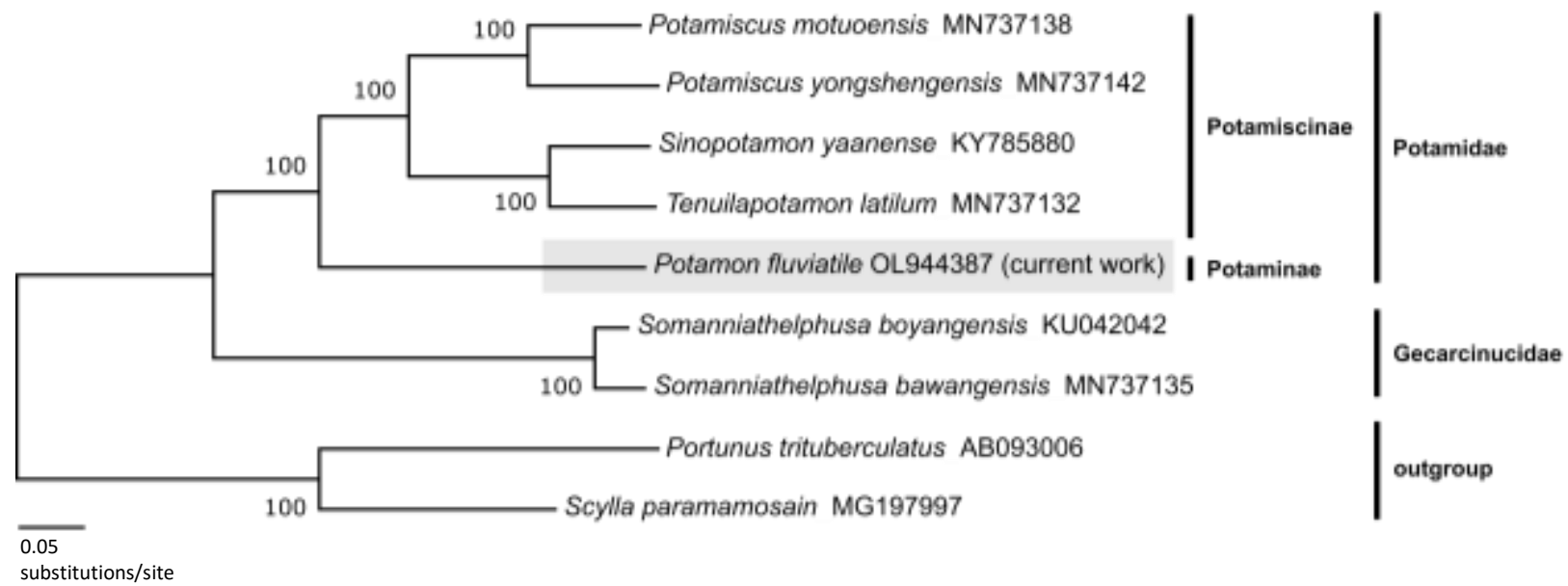

Figure 1. A maximum-likelihood tree using the 13 protein-coding and the two rRNA coding genes to show the phylogenetic relationship between Potamon fluviatile and other freshwater crabs of the family Potamidae and Gecarcinucidae, using two marine carbs as an outgroup (Jia et al., 2018; Yamauchi, Miya \& Nishida, 2003; Yuhui et al., 2017; Zhong et al., 2017; Zhang et al., 2020). Bootstrap values are indicated at each node.

\section{Author Contribution}

Both AV and NV contributed towards the design of the research, sample collection, laboratory analyses, data analyses and manuscript writing. Both authors approved the final manuscript.

\section{Conflict of Interest}

The authors declare that there is no conflict of interest.

\section{Acknowledgements}

The authors would like to thank the Environment Resource Authority (ERA) for providing the required permit (Permit NP 0176/18/33A) for the handling and tissue sampling of the specimen analysed in this study.

\section{References}

Bai, J., Xu, S., Nie, Z., Wang, Y., Zhu, C., Wang, Y., Min, W., Cai, Y., Zou, J. \& Zhou, X. (2018). The complete mitochondrial genome of Huananpotamon lichuanense (Decapoda: Brachyura) with phylogenetic implications for freshwater crabs. Gene, 646: 217-226. https://doi.org/10.1016/j.gene.2018.01.015

Barbaresi, S., Cannicci, S., Vannini, M. \& Fratini, S. (2007). Environmental correlates of two macro-decapods distribution in Central Italy: Multi-dimensional ecological knowledge as a tool for conservation of endangered species. Biological Conservation, 136: 431-441. https://doi.org/10.1016/j.biocon.2006.12.013

Chan, P.P. \& Lowe, T.M. (2019). tRNAscan-SE: Searching for tRNA Genes in Genomic Sequences. Methods in Molecular Biology, 1962: 1-14. https://doi.org/10.1007/978-1-4939-9173-0_1

Cui, Y.Y., Shi, L.B., Ji, W.B., Xu, S.X., Zhu, C.C., Zhou, X.M. \& Zou, J.X. (2020). The complete mitochondrial genome of the freshwater crab Chinapotamon maolanense (Decapoda:
Brachyura: Potamoidea). Mitochondrial DNA B Resources, 5(3):2357-2359. https://doi.org/10.1080/23802359.2020.1773330

Cumberlidge, N. (2008). Potamon fluviatile. The IUCN Red List of Threatened Species 2008: eT134293A3933275 [Accessed: 15-09-2021].

Cumberlidge, N., Ng, P.K.L., Yeo, D.C.J., Magalhães, C., Campos, M. R., Alvarez, F., Naruse, T., Daniels, S. R., Esser, L. J., Attipoe, F. Y. K., Clotilde-Ba, F. L., Darwall, W., Mclvor, A., Baillie, J. E. M., Collen, B. \& Ramj, M. (2009). Freshwater crabs and the biodiversity crisis: Importance, threats, status, and conservation challenges. Biological Conservation, 142: 1665-1673.

https://doi.org/10.1016/j.biocon.2009.02.038

Daniels, S.R., Cumberlidge, N., Perez-Losada, M., Marijnissen, S.A.E. \& Crandall, K.A. (2006). Evolution of Afrotropical freshwater crab lineages obscured by morphological convergence. Molecular Phylogenetics and Evolution, 40: 227-235.

https://doi.org/10.1016/j.ympev.2006.02.022

Freyhof, J. \& Brooks, E. (2011). European Red List of Freshwater Fishes. Luxembourg: Publications Office of the European Union. https://doi.org/10.2779/85903

Gao, N., Cui, Y.Y., Wang, S.B. \& Zou, J.X. (2019). Two new species and the molecular phylogeography of the freshwater crab genus Bottapotamon (Crustacea: Decapoda: Brachyura: Potamidae). PeerJ, 7: e7980. https://doi.org/10.7717/peerj.7980

Gozlan, R.E., Karimov, B.K., Zadereev, E. Kuznetsova D. \& Brucet S. (2019). Status, trends, and future dynamics of freshwater ecosystems in Europe and Central Asia. Inland Waters, 9(1): 78-94. https://doi.org/10.1080/20442041.2018.1510271

Grzybowski, M. \& Glińska-Lewczuk, K. (2019). Principal threats to the conservation of freshwater habitats in the continental biogeographical region of Central Europe. Biodiversity and Conservation, 28: 4065-4097. https://doi.org/10.1007/s10531-019-01865-x

Harlıoğlu, M.M., Farhadi, A. \& Harlıoğlu, A.G. (2018). A review of the freshwater crabs of Turkey (Brachyura, Potamidae). Fisheries and Aquatic Life, 26: 151-158. https://doi.org/10.2478/aopf-2018-0016 
Huang, C., Shih, H.T. \& Mao, S.Y. (2016). Yuebeipotamon calciatile, a new genus and new species of freshwater crab from southern China (Crustacea, Decapoda, Brachyura, Potamidae). Zookeys 615: 61-72. https://doi.org/10.3897/zookeys.615.9964

Jesse, R., Grudinski, M., Klaus, S., Streit, B. \& Pfenninger, M. (2011). Evolution of freshwater crab diversity in the Aegean region (Crustacea: Brachyura: Potamidae). Molecular Phylogenetics and Evolution, 59: 23-33. https://doi.org/10.1016/j.ympev.2010.12.011

Jesse, R., Pfenninger, M., Fratini, S., Scalici, M., Streit, B. \& Schubart, C.D. (2009). Disjunct distribution of the Mediterranean freshwater crab Potamon fluviatile natural expansion or human introduction? Biological Invasions, 11: 2209. https://doi.org/10.1007/s10530- 008-9377-0

Jesse, R., Schubart, C.D. \& Klaus, S. (2010). Identification of a cryptic lineage within Potamon fluviatile (Herbst) (Crustacea: Brachyura: Potamidae). Invertebrate Systematics, 24: 348-356. https://doi.org/10.1071/IS10014

Ji, W.B., Cui, Y.Y., Xu, S.X., Jia, X.N., Zhu, C.C., Zhou, X.M. \& Zou, J.X. (2019). The complete mitochondrial genome of the freshwater crab Sinolapotamon patellifer (Decapoda: Brachyura: Potamoidea). Mitochondrial DNA B Resources, 4(2): 2451-2453. https://doi.org/10.1080/23802359.2019.1637791

Jia, X. N., Xu, S. X., Bai, J., Wang, Y. F., Nie, Z. H., Zhu, C. C., Wang, Y., Cai, Y. X., Zou, J. X. \& Zhou, X. M. (2018). The complete mitochondrial genome of Somanniathelphusa boyangensis and phylogenetic analysis of genus Somanniathelphusa (Crustacea: Decapoda: Parathelphusidae). PloS one, 13(2), e0192601. https://doi.org/10.1371/journal.pone.0192601

Kearse, M., Moir, R., Wilson, A., Stones-Havas, S., Cheung, M., Sturrock, S., Buxton, S., Cooper, A., Markowitz, S., Duran, C., Thierer, T., Ashton, B., Mentjies, P. \& Drummond, A. (2012). Geneious basic: an integrated and extendable desktop software platform for the organization and analysis of sequence data. Bioinformatics, 28: 16471649. https://doi.org/10.1093/bioinformatics/bts199

Klaus, S., Brandis, D., Ng, P.K.L., Yeo, D.C.J. \& Schubart, C.D. (2009). Phylogeny and biogeography of Asian freshwater crabs of the family Gecarcinucidae (Brachyura: Potamoidea). In: Martin, J. W., Crandall, K. A. \& Felder, D. L. editors. Crustacean Issues 18: Decapod Crustacean Phylogenetics. Boca Raton (FL): CRC Press. p. 509-531. https://doi.org/10.1201/9781420092592

Kumar, S., Stecher, G., Li, M., Knyaz, C. \& Tamura, K. (2018). MEGA X: Molecular Evolutionary Genetics Analysis across computing platforms. Molecular Biology and Evolution, 35: 1547-1549. https://doi.org/10.1093/molbev/msy096

Laslet, D. \& Canbäck, B. (2007). ARWEN: a program to detect tRNA genes in metazoan mitochondrial nucleotide sequences. Bioinformatics, 24, 172-175. https://doi.org/10.1093/bioinformatics/btm573

Laws of Malta (2020).

http://www.justiceservices.gov.mt/LOM.aspx?pageid=2 7\&mode=chrono [Accessed: 15-09-2020].

Leelawathanagoon, P., Lheknim, V. \& Ng, P.K.L. (2010). On a new species of freshwater crab of the genus Terrapotamon (Brachyura, Potamidae) from peninsular Thailand. Crustaceana, 83(1): 49-59. https://doi.org/10.1163/001121609X12481627024337
Liu, H., Jiang, F., Xu, S., Zhu, C., Zhou, X. \& Zou, J. (2019). The complete mitochondrial genome of Aparapotamon similium (Decapoda: Brachyura), an endemic to China. Mitochondrial DNA Part B Resources, 4:2, 2482-2484. https://doi.org/10.1080/23802359.2019.1638323

Naktang, C., Sonthirod, C., Sangsrakru, D., U-Thoomporn, S. Koipokaisawan, T., Panase, P., Tuntaisong, M., Pootakham, W. \& Tangphatsornruang, S. (2021). The complete mitochondrial genome sequence of the mountain crab Indochinamon bhumibol. Mitochondrial DNA Part B Resources, 6(2), 634-635. https://doi.org/10.1080/23802359.2021.1877203

Naruse, T., Chia, J. E., \& Zhou, X. (2018). Biodiversity surveys reveal eight new species of freshwater crabs (Decapoda: Brachyura: Potamidae) from Yunnan Province, China. PeerJ, 6: e5497. https://doi.org/10.7717/peerj.5497

Ng, P.K.L., Guinot, D., \& Davie, P.J. (2008). Systema Brachyurorum: Part I. An annotated checklist of extant brachyuran crabs of the world. The Raffles Bulletin of Zoology, 17: 1-286. https://doi.org/10.1016/j.ympev.2019.106669

Segawa, R.D., Aotsuka, T. (2005). The mitochondrial genome of the Japanese freshwater crab, Geothelphusa dehaani (Crustacea: Brachyura): evidence for its evolution via gene duplication. Gene, 355: 28-39. doi: 10.1016/j.gene.2005.05.020

Shih, H.T., Yeo, D.C.J. \& Ng, P.K.L. (2009). The collision of the Indian plate with Asia: molecular evidence for its impact on the phylogeny of freshwater crabs (Brachyura: Potamidae). Journal of Biogeography, 36: 703-719. https://doi.org/10.1111/j.1365-2699.2008.02024.x

Tan, Q.H., Zhou, X.J., Zou, J.X. (2021). Two new species of freshwater crab of the genus Aparapotamon Dai \& Chen, 1985 (Crustacea, Brachyura, Potamidae) from Yunnan, China. ZooKeys, 1056: 149-171. https://doi.org/10.3897/zookeys.1056.63755

Tan, Q.H., Zhu, C.C., Zhou, X.J., Xu, S.X., Zhang, L.Y., Shi, L.B. \& Zou, J.X. (2020). The complete mitochondrial genome of the freshwater crab Neilupotamon xinganense (Decapoda: Brachyura: Potamoidea). Mitochondrial DNA B Resources, 5(3): 2544-2546. https://doi.org/10.1080/23802359.2020.1781570

Thompson, J.D., Higgins, D.G. \& Gibson, T.J. (1994). CLUSTALW: improving the sensitivity of progressive multiple sequence alignment through sequence weighting, position- specific gap penalties and weight matrix choice. Nucleic Acids Resources, 22(22): 4673 4680. https://doi.org/10.1093/nar/22.22.4673

Tsang, L.M., Schubart, C.D., Ahyong, S.T., Lai, J.C., Au, E.Y., Chan, T.Y., Ng, P.K. \& Chu, K.H. (2014). Evolutionary history of true crabs (Crustacea: Decapoda: Brachyura) and the origin of freshwater crabs. Molecular Biology and Evolution, 31(5): 1173-1187. https://doi.org/10.1093/molbev/msu068

Vella, A., \& Vella, N. (2020). First Population Genetic Structure Analysis of the Freshwater Crab Potamon fluviatile (Brachyura: Potamidae) Reveals Fragmentation at Small Geographical Scale. Genaqua, 4(1), 49-59. http://doi.org/10.4194/2459-1831-v4_1_05

Vella, N., Vella, A. \& Mifsud, C.M. (2017). First Scientific Records of the Invasive Red Swamp Crayfish, Procambarus clarkii (Girard, 1852) (Crustacea: Cambaridae) in Malta, a Threat to Fragile Freshwater Habitats. Natural and Engineering Sciences, 2: 58-66. https://doi.org/10.28978/nesciences.328931 
Wang, Q., Wang, J., Wu, Q., Xu, X., Wang, P. \& Wang, Z. (2021). Insights into the evolution of Brachyura (Crustacea: Decapoda) from mitochondrial sequences and gene order rearrangements. International Journal of Biological Macromolecules, 170: 717-727. https://doi.org/10.1016/j.ijbiomac.2020.12.210

Wang, S.B, Zhou, X.M. \& Zou, J.X. (2019). A new species of freshwater crab of the genus Mediapotamon Türkay \& Dai, 1997 (Crustacea, Decapoda, Brachyura, Potamidae) from Guizhou, China. ZooKeys 873: 9-23. https://doi.org/10.3897/zookeys.873.36702

Wang, S.B., Zhang, Y.N. \& Zou, J.X. (2020). A new species of freshwater crab of the genus Qianguimon Huang, 2018 (Decapoda: Brachyura: Potamidae) from Guangxi, Southern China. PeerJ, 8: e9194. https://doi.org/10.7717/peerj.9194

Wang, Y., Xu, S., Zhu, C., Jia, X., Zhou, X., \& Zou, J. (2020). The complete mitochondrial genome of the freshwater $\mathrm{crab}$ Longpotamon kenliense (Decapoda, Brachyura, Potamidae) with phylogenetic consideration. Studies on the Taxonomy of Crustaceans, 45-61. https://doi.org/10.1163/9789004464353_005

Wang, Y.F., Yang, Q., Xu, S.X., Zhao, M.J. \& Zou, J.X. (2021). The complete mitochondrial genome of the freshwater crab Bottapotamon lingchuanense Türkay and Dai 1997 (Decapoda: Brachyura: Potamoidea). Mitochondrial DNA B Resources, 6(4): 1554-1556. https://doi.org/10.1080/23802359.2021.1915208

Xing, Y.H., Zhou, L.J., Hou, Y., Wang, X.Q., Zhang, C. \& Zhang, H.L. (2017). Complete mitochondrial genomes from two species of Chinese freshwater crabs of the genus Sinopotamon recovered using next-generation sequencing reveal a novel gene order (Brachyura, Potamidae). ZooKeys, 705: 41-60. https://doi.org/10.3897/zookeys.705.11852
Yamauchi, M.M., Miya, M.U., \& Nishida, M. (2003). Complete mitochondrial DNA sequence of the swimming crab, Portunus trituberculatus (Crustacea: Decapoda: Brachyura). Gene, 311: 129-35. doi: 10.1016/s0378 1119(03)00582-1

Yeo, D.C.J., Ng, P.K.L., Cumberlidge, N., Magalhaes, C., Daniels, S.R. \& Campos, M.R. (2008). Global diversity of crabs (Crustacea: Decapoda: Brachyura) in freshwater. Hydrobiologia, 595: 275-286. https://doi.org/10.1007/s10750-007-9023-3

Yuhui, X., Lijun, Z., Yue, H., Xiaoqi, W., Chen, Z., Huilun, Z., Ruoran, W., Da, P. \& Hongying, S. (2017). Complete mitochondrial genomes from two species of Chinese freshwater crabs of the genus Sinopotamon recovered using next-generation sequencing reveal a novel gene order (Brachyura, Potamidae). ZooKeys, 705: 41-60. https://doi.org/10.3897/zookeys.705.11852

Zhang, Z., Xing, Y., Cheng, J., Pan, D., Lv, L., Cumberlidge, N. \& Sun, H. (2020). Phylogenetic implications of mitogenome rearrangements in East Asian potamiscine freshwater crabs (Brachyura: Potamidae). Molecular Phylogenetics and Evolution, 143: 106669. https://doi.org/10.1016/j.ympev.2019.106669

Zhong, S., Zhao, Y., Wang, X., Song, Z. \& Zhang, Q. (2017). The complete mitochondrial genome of Scylla paramamosain (Decapoda: Portunidae). Mitochondrial DNA B Resources, 2(2): 789-790. https://doi.org/10.1080/23802359.2017.1398617

Zou, J.X., Bai, J. \& Zhou, X.M. (2018). A new species of karstdwelling freshwater crab of the genus Chinapotamon Da \& Naiyanetr, 1994 (Crustacea: Decapoda: Brachyura: Potamidae), from Guizhou, southwest China. PeerJ, 6: e5947. https://doi.org/10.7717/peerj.5947 